\title{
Impact of Forest Road Construction on Topsoil Erosion and Hydro-Physical Soil Properties in a Semi-Arid Mountainous Ecosystem in Turkey
}

\author{
Sezgin Hacisalihoğlu*, Selçuk Gümüş, Uğur Kezik, Hakan Karadağ \\ Karadeniz Technical University, Faculty of Forestry, Forest Engineering Department, Trabzon, Turkey
}

Received: 10 October 2017

Accepted: 28 December 2017

\begin{abstract}
This study aimed at pointing out the environmental importance of road construction in a semi-arid high mountainous area on soil erosion and some important soil properties throughout the forest road. In total 60 soil samples in both forest and open area were collected from topsoil $(0-20 \mathrm{~cm})$ of a cut slope, fill slope, and control points along with a forest road route. The soil properties were determined in the laboratory and the soil loss amounts were determined by way of an Allgemeine Boden Abtrags Gleichung $(A B A G)$ simulation model.

As a result, the road construction phase significantly changed $(\mathrm{p}<0.001)$ the soil erosion trend. Annual soil loss amounts ( $\mathrm{t} / \mathrm{ha} / \mathrm{yr}$.) determined cut slope $>$ fill slope $>$ control in both forest and open areas. Consequently, road construction efforts significantly affected topsoil loss and some soil properties such as organic matter, available water-holding capacity, and bulk density. According to the created scenario, under the same slope $(68.72 \%)$ and slope length $(3.26 \mathrm{~m})$ conditions, the highest soil loss trend was in cut slope, which was significantly different $(\mathrm{p}<0.001)$ from fill slope and control in forested and open areas.
\end{abstract}

Keywords: afforestation effects, soil loss, forest road, ecological assessment, $A B A G$

\section{Introduction}

Soil properties and erosion level in forest ecosystems have been affected by ecological factors such as land use [1], climate [2], terrain [3], soil characteristics [4], and species composition [5]. However, silvicultural activities (tending and harvesting) and anthropogenic events also have important effects on soil erosion and soil properties

*e-mail: sezgin@ktu.edu.tr
[6]. Although they are important in rural development, timber production, and eco-tourism activities, forest roads are among the anthropogenic effects that adversely affect soil quality characteristics in forest ecosystems [7-8]. In a forest ecosystem during the road construction stage, fertile topsoil rich in organic matter, suitable for bulk density and permeability, and erosion-resistant is stripped from the surface and surface slope is changed. This changes the structure of soil as it is bared and compacted for the construction area. Therefore, soil loss by erosion and surface runoff are accelerated 
in both cut and fill slope surfaces of forest roads. These effects emerge as the most important factor affecting and determining soil loss by erosion [9].

Forest roads undertake the basic infrastructure of forestry management activities and are constructed at different densities, considering different purposes within the management units. As a result, in forestry activities, the construction of forest roads is at the top of the factors that constitute the most environmental damage. It has been reported that forest roads cause many adverse effects on soil properties and increase surface runoff and erosion, resulting in massive transport of soil after heavy rainfall [10].

In forest ecosystems, pathways (in addition to natural and artificial channels) create a stream with surface runoff and contribute to sediment in the forested watershed [11]. Zemke [12] applied simulated smallscale precipitation to forest roads at different levels and found that the surface runoff was 25 times more than the control area.

So far, many studies have been conducted related to environmental and ecological effects of forest road surfaces and roads [13-15]. However, studies investigating the effects of slopes (fill and cut slope) on forest roads on soil erosion and properties are rather limited. In addition to the cut slopes, their lengths also affect soil loss [16]. In parallel with the increase in cut slope length, sediment yield also increases [11]. Soil particle size also has a significant effect on the amount of soil loss. Cut slopes and their lengths affect soil loss due to its slope gradient, which is $100 \%$ in cut slopes and approximately $70 \%$ in fill slopes. It is known that soil particle $(<2.0 \mathrm{~mm})$ size distribution has a significant effect on soil loss amounts because of its significant effects on soil hydro-physical behaviors. Sediment yield on silty clay loam textured road surface is reported to be about 9 times higher than that of a graveled loamy road surface [11].
This study first aimed to investigate the annual soil loss amount and affecting factors on the road slope (cut and fill) surfaces along with the forest road segment in the field of a 40 -year-old scoth pine plantation in a semiarid region. Secondly, to determine effects of forest road construction on forest and open areas by comparing differences in soil loss and soil properties between cut and fill slopes. Finally, we attempted to define necessary precautions that will be reduced the amount of soil erosion in road slopes.

\section{Experimental}

\section{Location}

The study area is on the Eastern Black Sea Region of Turkey in Işık village Torul Gümüşhane, $\left(40^{\circ} 22^{\prime} 58^{\prime \prime}\right.$ $\mathrm{N}-39^{\circ} 17^{\prime} 35^{\prime \prime}$ E, elevation: 1,919-2,055 m a.s.l.; Fig. 1). The main aspect is the north and average terrain slope is $69 \%$. The study area is approximately $60 \mathrm{~km}$ from center of Gümüşhane Province (Fig. 1).

\section{Climate}

According to climate data of the last 55 years, the average annual temperature is $9.7^{\circ} \mathrm{C}$ and total annual precipitation is $464.2 \mathrm{~mm}$. A balanced rainfall is observed throughout the year; but according to Walter [17], the climate diagram in this region sees a water shortage in throughout July, August, and September (Fig. 2). In addition, the study area is classified as "semi-arid," according to Aydeniz climate classification; "steppe humid," according to DeMartonne; and " $\mathrm{C}_{1}$, semi dry-less humid," according to the Thornthwaite method [18].

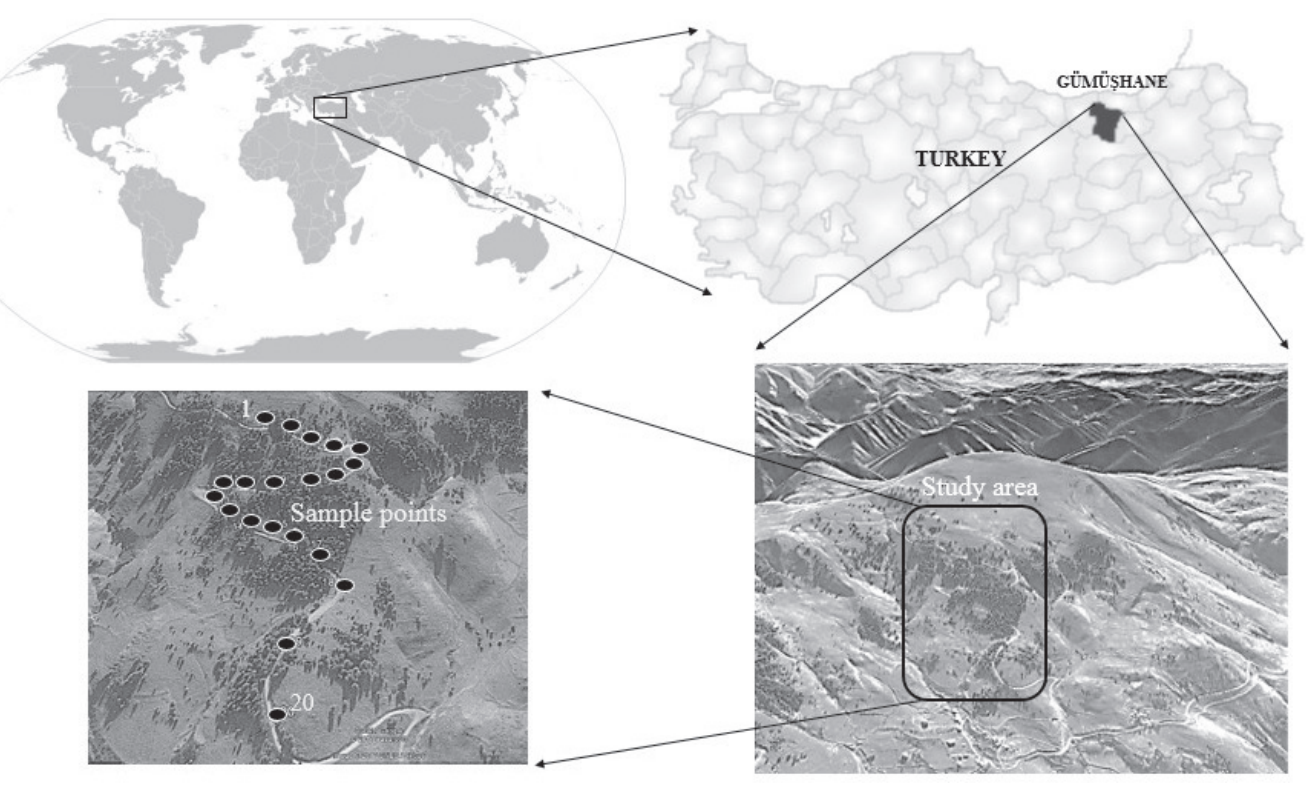

Fig. 1. Study area location and sample points. 


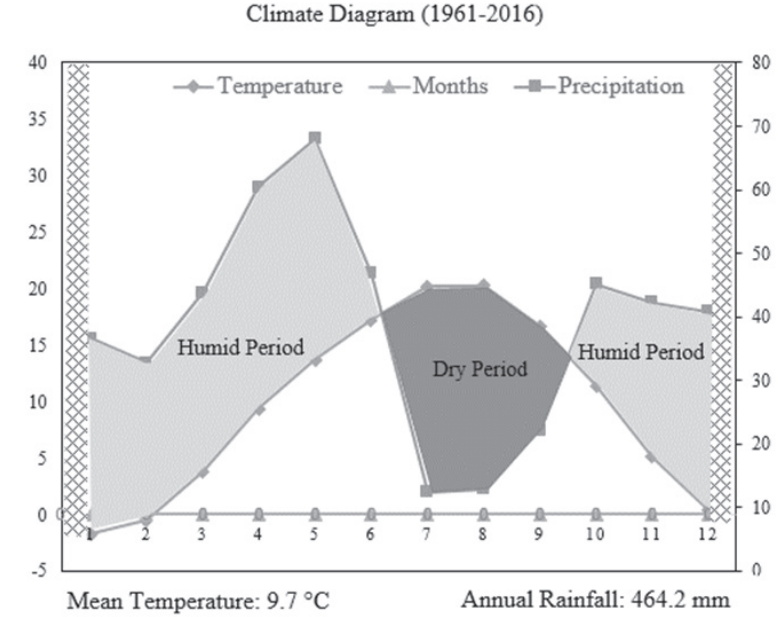

Fig. 2. Walter climate diagram of research area.

\section{Forest Road and Stand Structure}

Generally, forest road construction is carried out by arranging the slope surfaces on both sides of the road platform and road by processing the natural ground with various excavators. Road platforms are constructed by the excavation process according to the zero line on the forest roads, and excavation is carried out from the beginning of the excavation to $1 / 1$ rate (up to the level of the road platform), and the material is stored in the slope downwards direction. The surface of the filling slope formed by excavated material storage becomes stabilized by $2 / 3$ ratio. The surface of the excavation slope ( $100 \%$ slope) is formed by excavating the natural ground, and the surface of the slope (approximately 70\% slope) formed by free storage of the excavated material remains open to erosive effects.
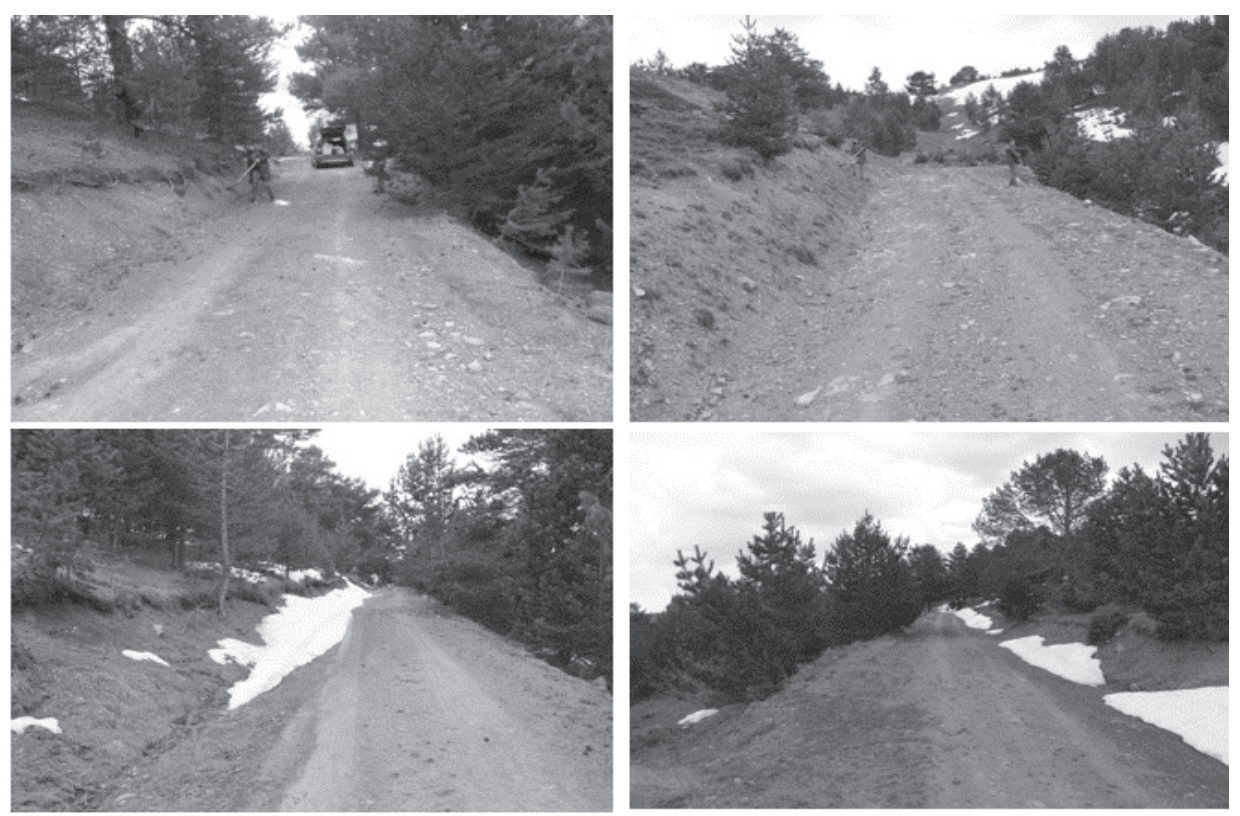

Fig. 3. Structure of forest road in study area.

The forest road in the study area is a 4-m platform wide low-volume secondary forest road constructed without asphalt (Fig. 3). Sampling was carried out at the cut slope, fill slope, and control points along the road route of about $1,000 \mathrm{~m}$ in the study area. Cut slope value was $100 \%$ and fill slope was $70 \%$ constantly in open and forested areas. Besides, slopes in control points and slope lengths in all slope type were inconstant. The average slope and slope length of the study area were $68.72 \%$ and $3.26 \mathrm{~m}$, respectively.

The study area was successfully planted in the 1970 s with the species Pinus sylvestris. The current age of the forested area is about 40 years. When the area is considered as a height elevation, the average elevation is high and forms the top of the timber line. The geological structure is from the upper cretaceous period and parent material is of quartz andesite form. Soil is textured generally as sandy clay loam in both land use types (forested and open areas). The canopy closure of the forested area is around $70 \%$. Herbaceous plants dominate the open area.

\section{Data Collection}

\section{Soil Sampling and Soil Loss Estimation by ABAG (Allgemeine Boden Abtrags Gleichung)}

In total 60 sample plots were taken in forested and open areas from control, fill slope, and cut slope respectively (Fig. 4). At these plots, soil samples were collected from topsoil $(0-20 \mathrm{~cm})$ along with the road route. And in soil analysis, air-dried and sieved $(<2.0 \mathrm{~mm})$ soil particles were used to determine soil particle size distribution such as sand (\%), silt (\%), and clay (\%) ratio depending on the Bouyoucos hydrometer method [19]. Soil $\mathrm{pH}$ was determined 


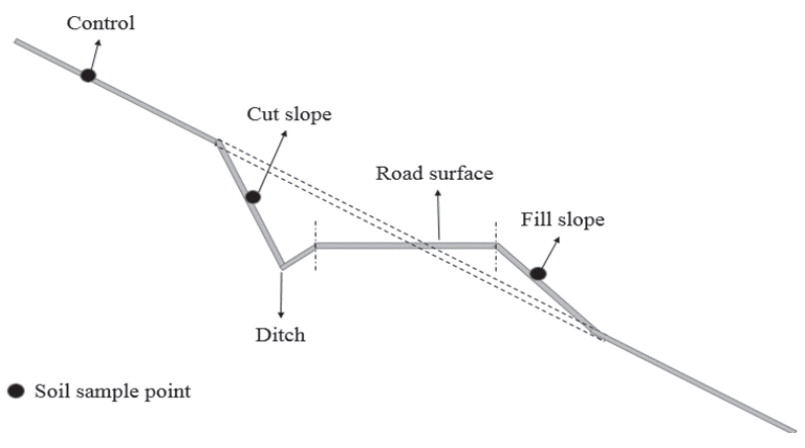

Fig. 4. Soil sampling points along the road slope in forest and open areas.

by using a digital $\mathrm{pH}$ meter (Hach Company, USA) and the organic matter content by the WalkleyBlack wet oxidation method [20] in laboratory conditions. Permeability class and the other hydrophysical soil properties such as field capacity (\%), wilting point $(\%)$, saturation $(\%)$, saturated hydraulic conductivity $(\mathrm{cm} / \mathrm{hr})$, and bulk density are described according to Saxton's hydraulic properties calculator [21]. Surface stoniness (\%), slope gradient (\%), and aggregate class, etc. are determined separately at each sampling point [22].

In this study, to estimation soil loss, $A B A G$ is the international version (where the values are turned in to the metric system and adapted to European conditions) of the simulation universal soil loss equation (USLE) model was used based on the Schwertmann et al. model [23], which is used at a global level to determine soil loss by erosion:

$$
\mathrm{A}=\mathrm{K} \times \mathrm{R} \times \mathrm{LS} \times \mathrm{C} \times \mathrm{P}
$$

...where A is average annual soil loss ( $\mathrm{t} / \mathrm{ha}$ per year), $\mathrm{K}$ is soil erodibility factor, $\mathrm{R}$ is rainfall erosivity factor, LS slope and slope length factor (L: slope lenght, $\mathrm{S}$ : slope degree), $\mathrm{C}$ is the cover management factor, and $\mathrm{P}$ is the supporting practice factor. $\mathrm{K}, \mathrm{LS}, \mathrm{C}$, and $\mathrm{P}$ factors have been estimated by equations, monographs, and predetermined coefficient [23]. R value was taken from Dogan and Gücer's study [24].

Soil loss equation values in our study include $\mathrm{R}$ taken as 75.0, $\mathrm{P}$ was 1.0 , and $\mathrm{C}$ was 0.030 for forest and 0.130 for open areas, respectively. LS and K values were calculated for each sample plot by using equations and monographs [23].

Slope lengths and slope gradients at all sample plots were measured by a steel tape meter and clizimeter, respectively. The fill slope was accepted that has $70 \%$ as slope (S) and the cut slope as $100 \%$ due to the structure of road construction as aforementioned. However, LS values were calculated to be different at all sample plots due to slope lengths (L). P and $\mathrm{R}$ values were taken as fixed value for all sample points.

\section{Statistical Analysis}

Obtained soil properties and soil loss quantities at the cut slope, fill slope, and control points in the forested and open area were tested using the SPSS program (version 23.0 software package, Institute Inc., Chicago, IL, USA, 2016). Soil properties and estimated soil loss amounts compared to each other depend on cut and fill slope and control points for forested and open areas using one-way Anova-Tukey test. A scenario was created for clear explanation of the effects of slope and slope length on soil loss in the study area. It is assumed that the cut slope, fill slope, and control points in the open areas and forests have the same slope and slope length values (average of 60 points measured; slope: $68.72 \%$, slope length: $3.27 \mathrm{~m}$ ). In this scenario, the amount of soil loss in the slopes was compared using one-way Anova-Tukey test. And soil loss and other soil properties also were compared with one another in slopes depending on land use type (forested and open areas) by independent samples T-test. Results are expressed as means $\pm \mathrm{SE}$ (standard error). Statistical significance was defined as $\mathrm{P}<0.05$ and $<0.01$ and $\mathrm{p}<0.001$.

\section{Results and Discussion}

Overall, in a period of 40 years, road construction studies in open and forested areas have not significantly altered the soil hydro-physical properties such as soil texture (sand, silt, and clay ratio), field capacity (\%), wilting point $(\%)$, available water-holding capacity $(\%)$, and saturated hydraulic conductivity $(\mathrm{cm} / \mathrm{hr})$. However, soil organic matter $(\%), \mathrm{pH}$, and bulk density $\left(\mathrm{gr} / \mathrm{cm}^{3}\right)$ have been significantly changed, causing maximum water-holding capacity (saturation, \%) of the soil to be adversely affected.

In our study area, the amount of soil loss in open and forested areas was significantly affected by LS factor of slope gradient and slope length components. And it was also significantly affected by $\mathrm{K}$ factor, which is an indicator of soil properties. The $\mathrm{C}$ coefficient affected by land use regime and vegetation cover used in the soil loss equation also played an important role in lowering the calculated soil loss in the forest area compared to the open area. Soil loss amounts in control, fill, and cut slopes in both forested and open areas were significantly different from each other due to K and LS factors.

The changes in soil loss amounts and soil characteristics according to land use (forested and open areas) and slopes are discussed in detail below.

\section{Changing Soil Loss and Other Soil Properties Depending on Road Slopes in Open Areas}

The relationships between measured and estimated values depending on slopes in an open area are given in Table 1. Soil properties such as sand, silt, field capacity, 
Table 1. Soil properties and some soil loss components in open areas (Mean $\pm \mathrm{SE}$ ).

\begin{tabular}{|c|c|c|c|}
\hline Parameters & Control & Fill Slope & Cut Slope \\
\hline Sand (\%) & $62.80^{\mathrm{a}} \pm 1.51$ & $60.17^{\mathrm{a}} \pm 1.71$ & $16.49^{\mathrm{a}} \pm 2.19$ \\
\hline Silt (\%) & $16.53^{\mathrm{a}} \pm 1.82$ & $16.53^{\mathrm{a}} \pm 0.86$ & $25.41^{\mathrm{bc}} \pm 1.39$ \\
\hline Clay (\%) & $20.68^{\mathrm{a}} \pm 0.81$ & $23.31^{\mathrm{ab}} \pm 1.51$ & $3.36^{\mathrm{a}} \pm 0.53$ \\
\hline OM (\%) & $5.65^{\mathrm{b}} \pm 0.59$ & $3.45^{\mathrm{a}} \pm 0.32$ & $6.27^{\mathrm{a}} \pm 0.07$ \\
\hline pH & $6.06^{\mathrm{a}} \pm 0.05$ & $6.25^{\mathrm{a}} \pm 0.12$ & $28.57^{\mathrm{a}} \pm 1.07$ \\
\hline Field capacity (\%) & $27.92^{\mathrm{a}} \pm 0.85$ & $26.41^{\mathrm{a}} \pm 0.96$ & $17.80^{\mathrm{a}} \pm 1.00$ \\
\hline Wilting point (\%) & $16.95^{\mathrm{a}} \pm 0.65$ & $15.90^{\mathrm{a}} \pm 0.72$ & $44.36^{\mathrm{a}} \pm 1.34$ \\
\hline Saturation (\%) & $50.14^{\mathrm{b}} \pm 1.37$ & $45.71^{\mathrm{a}} \pm 0.75$ & $0.05^{\mathrm{a}} \pm 0.00$ \\
\hline AWHC (cm/cm) & $0.05^{\mathrm{a}} \pm 0.00$ & $0.05^{\mathrm{a}} \pm 0.00$ & $0.49^{\mathrm{bc}} \pm 0.08$ \\
\hline Sat. Hyd. Cond. $(c m / h r)$ & $1.10^{\mathrm{a}} \pm 0.15$ & $0.75^{\mathrm{ab}} \pm 0.12$ & $1.45^{\mathrm{bc} \pm 0.02}$ \\
\hline Bulk density (gr/cm $\left.{ }^{3}\right)$ & $1.32^{\mathrm{a}} \pm 0.04$ & $1.44^{\mathrm{b}} \pm 0.02$ & $2.84^{\mathrm{a}} \pm 0.30$ \\
\hline L_Factor & $3.36^{\mathrm{a}} \pm 0.38$ & $3.65^{\mathrm{a}} \pm 0.88$ & $13.13^{\mathrm{c}} \pm 0.73$ \\
\hline LS_Factor & $3.03^{\mathrm{a}} \pm 0.68$ & $8.23^{\mathrm{b}} \pm 1.07$ & $0.1151^{\mathrm{b}} \pm 0.0042$ \\
\hline K_Factor & $0.0740^{\mathrm{a}} \pm 0.0032$ & $0.0812^{\mathrm{a}} \pm 0.0017$ & \\
\hline
\end{tabular}

*Note: letters at the top indicate whether the measured parameters differ between slopes $(\mathrm{N}=10)(\alpha=.05)$

wilting point, available water-holding capacity (AWHC), and $\mathrm{pH}$ were not significantly $(\mathrm{p}>0.05)$ changed in slopes, while clay, organic matter, saturation, bulk density, and saturated hydraulic conductivity was significantly $(p<0.05)$ changed. Estimated soil loss amounts in slopes were significantly different $(\mathrm{p}<0.001)$ from each other and were about $4.940 \mathrm{t} / \mathrm{ha} / \mathrm{yr}$ in cut slope, $2.191 \mathrm{t} / \mathrm{ha} / \mathrm{yr}$ in fill slope, and $0.717 \mathrm{t} / \mathrm{ha} / \mathrm{yr}$ in control slope, respectively (Table 3). In a study in Spain, average soil loss amount in a road route of an open area was measured as $3.0 \mathrm{t} / \mathrm{ha} / \mathrm{yr}$ [26]. We found that soil loss in cut slope was approximately 2.5 times higher than fill slope. On the other hand, in a study it was found that the effects of road slopes on calculated soil loss were to be 6 times greater

Table 2. Soil properties and some soil loss components in forested areas (Mean $\pm \mathrm{SE}$ ).

\begin{tabular}{|c|c|c|c|}
\hline Parameters & Control & Fill Slope & Cut Slope \\
\hline Sand (\%) & $59.33^{\mathrm{a}} \pm 1.48$ & $62.59^{\mathrm{a}} \pm 2.08$ & $13.22^{\mathrm{a}} \pm 2.49$ \\
\hline Silt (\%) & $14.84^{\mathrm{a}} \pm 1.07$ & $12.42^{\mathrm{a}} \pm 1.14$ & $29.41^{\mathrm{a}} \pm 2.60$ \\
\hline Clay (\%) & $25.83^{\mathrm{a}} \pm 1.19$ & $24.99^{\mathrm{a}} \pm 1.56$ & $3.02^{\mathrm{a}} \pm 0.41$ \\
\hline OM (\%) & $4.70^{\mathrm{b}} \pm 0.30$ & $3.09^{\mathrm{a}} \pm 0.29$ & $6.11^{\mathrm{bc}} \pm 0.04$ \\
\hline pH & $5.83^{\mathrm{a}} \pm 0.09$ & $5.91^{\mathrm{ab}} \pm 0.08$ & $29.89^{\mathrm{a}} \pm 1.56$ \\
\hline Field capacity (\%) & $29.70^{\mathrm{a}} \pm 0.68$ & $26.88^{\mathrm{a}} \pm 1.21$ & $19.67^{\mathrm{a}} \pm 1.31$ \\
\hline Wilting point (\%) & $19.01^{\mathrm{a}} \pm 0.57$ & $17.01^{\mathrm{a}} \pm 0.92$ & $44.74^{\mathrm{a}} \pm 0.76$ \\
\hline Saturation (\%) & $47.36^{\mathrm{b}} \pm 0.65$ & $44.24^{\mathrm{a}} \pm 0.39$ & $0.05^{\mathrm{a}} \pm 0.00$ \\
\hline AWHC (cm/cm) & $0.05^{\mathrm{a}} \pm 0.00$ & $0.05^{\mathrm{a}} \pm 0.00$ & $0.45^{\mathrm{a}} \pm 0.16$ \\
\hline Sat. Hyd. Cond. (cm/hr) & $0.56^{\mathrm{a}} \pm 0.08$ & $0.55^{\mathrm{a}} \pm 0.09$ & $1.46^{\mathrm{b}} \pm 0.02$ \\
\hline Bulk density (gr/cm $)$ & $1.39^{\mathrm{a}} \pm 0.54$ & $1.48^{\mathrm{b}} \pm 0.03$ & $2.05^{\mathrm{b}} \pm 0.19$ \\
\hline L_Factor & $4.11^{\mathrm{a}} \pm 0.44$ & $3.55^{\mathrm{a}} \pm 0.36$ & $11.4612^{\mathrm{c}} \pm 0.4063$ \\
\hline LS_Factor & $3.9245^{\mathrm{a}} \pm 0.7287$ & $8.7405^{\mathrm{b}} \pm 0.3790$ & $0.1017^{\mathrm{b}} \pm 0.0048$ \\
\hline K_Factor & $0.0749^{\mathrm{a}} \pm 0.0020$ & $0.0784^{\mathrm{a}} \pm 0.0030$ & \\
\hline
\end{tabular}

*Note: letters at the top indicate whether the measured parameters differ between slopes $(N=10)(\alpha=.05)$ 
Table 3. Soil loss group for forest and open areas.

\begin{tabular}{|c|c|c|c|c|c|c|c|c|}
\hline \multirow{2}{*}{ Sample point } & \multirow{2}{*}{ N } & \multicolumn{3}{|c|}{$\begin{array}{c}\text { Open Area } \\
\text { Subset for alpha }=.05\end{array}$} & \multicolumn{3}{c|}{$\begin{array}{c}\text { Forest } \\
\text { Subset for alpha }=.05\end{array}$} \\
\cline { 3 - 10 } & 1 & 1 & 2 & 3 & 1 & 2 & 3 \\
\hline \multirow{3}{*}{$\begin{array}{c}\text { Tukey } \\
\text { HSD(a) }\end{array}$} & Control & 10 & .71666040 & & & .22237380 & & \\
\cline { 2 - 10 } & Fill slope & 10 & & 2.190961 & & & .51643110 & \\
\cline { 2 - 10 } & Cut slope & 10 & & & 4.940255 & & & .87642810 \\
\cline { 2 - 9 } & Sig. & & 1.000 & 1.000 & 1.000 & 1.000 & 1.000 & 1.000 \\
\hline
\end{tabular}

*Means for groups in homogeneous subsets are displayed

than in fill slopes [27]. Even this ratio may reach as high as 16 times [28]. The open area conditions in our study are close to pasture conditions in the study site and the mean soil loss was estimated at $2.62 \mathrm{t} / \mathrm{ha} / \mathrm{yr}$. Average soil loss in pasture areas in Europe was reported to be about $2.00 \mathrm{t} / \mathrm{ha} / \mathrm{yr}$ [29]. Breetzke et al. [30] estimated annual soil loss of about $4.10 \mathrm{t} / \mathrm{ha} / \mathrm{yr}$ in grassland according to USLE.

The mean L-factor values in open areas were not significantly changed according to the slopes $(p>0.05)$. LS factor, which is one of the most important components of the soil loss equation $(A B A G)$, were statistically significant $(\mathrm{p}<0.01)$ because of the slope length in all sample points $(\mathrm{p}<0.01)$. Zhang et al. [1] reported that there is a close relationship between slope gradient $\left(\mathrm{R}^{2}>0.9\right)$ and soil loss in agriculture, and they measured soil loss of $7.70 \mathrm{t} / \mathrm{ha} / \mathrm{yr}$. The $\mathrm{K}$ factor, which is affected significantly by soil properties in control and fill slope, was significantly different from cut slope $(p<0.001$; Table 1). In our study, the average $\mathrm{K}$ factor ranged from 0.07 to 0.12 , while Kusumandari [31] found that the $\mathrm{K}$ value varied from 0.16 to 0.29 .

\section{Changing Soil Loss and Other Soil Properties Depend on Slopes in Forested Areas}

The relationships between measured and estimated values depending on slopes in forested areas are given in Table 2. Soil properties such as sand, silt, clay, field capacity, wilting point, available water-holding capacity (AWHC), and saturated hydraulic conductivity were not significantly changed $(\mathrm{p}>0.05)$. But organic matter, $\mathrm{pH}$, saturation, and bulk density were significantly changed, according to slopes $(\mathrm{p}<0.05)$. The amount of soil loss was calculated as $0.876 \mathrm{t} / \mathrm{ha} / \mathrm{yr}$ in the cut slope, $0.516 \mathrm{t} / \mathrm{ha} / \mathrm{yr}$ in the fill slope, and $0.222 \mathrm{t} / \mathrm{ha} / \mathrm{yr}$ in the control point, respectively, in forested areas (Table 3). It was reported in a study that more than $90 \%$ of the sediment yield coming from the road surface in a forested area resulted from the cut and fill slopes where the soil loss amounts determined $1.61 \mathrm{t} / \mathrm{ha} / \mathrm{yr}$ and $0.11 \mathrm{t} / \mathrm{ha} / \mathrm{yr}$, respectively [32]. A road constructed in a forested area causes significant changes in soil characteristics and sediment yield [14]. In our study, road construction significantly affected the soil loss amount in the forested area. In addition, the average soil loss from the forested area was calculated as $0.54 \mathrm{t} / \mathrm{ha} / \mathrm{yr}$. In a study in South Africa, soil loss was estimated at $0.60 \mathrm{t} / \mathrm{ha} / \mathrm{yr}$ in a plantation area [30]. However, annual soil loss in the planted area in Europe is reported as $0.07 \mathrm{t} / \mathrm{ha}$ [29]. There were also significant differences between the slopes, including control in our study area $(\mathrm{p}<0.001)$. However, the $\mathrm{L}$ factor in the cut slope was different from control and fill slope $(\mathrm{p}<0.05)$. The LS factor was found to be statistically different $(p<0.01)$ in both slopes and control. The mean of $K$ factor was significantly different $(p<0.001)$ in control and fill slopes in forested areas (Table 2). K factor determined by soil properties also is significantly affected by land use and soil depth [33]. In our study, the average $\mathrm{K}$ factor in the forested area was calculated as 0.08 , while Dindaroglu and Canbolat [34] reported the average $\mathrm{K}$ factor of the forest area in Eastern Anatolia as 0.05.

\section{Comparison of Soil Loss and Soil Properties in Slopes According to Land Use (Forested and Open Areas)}

Land use is one of the main determinants of surface runoff, soil loss, and sediment yield in a basin [35]. Significant alterations were found in the calculated amount of soil loss and some soil properties in open and forested areas. Depending on land use (open and forested

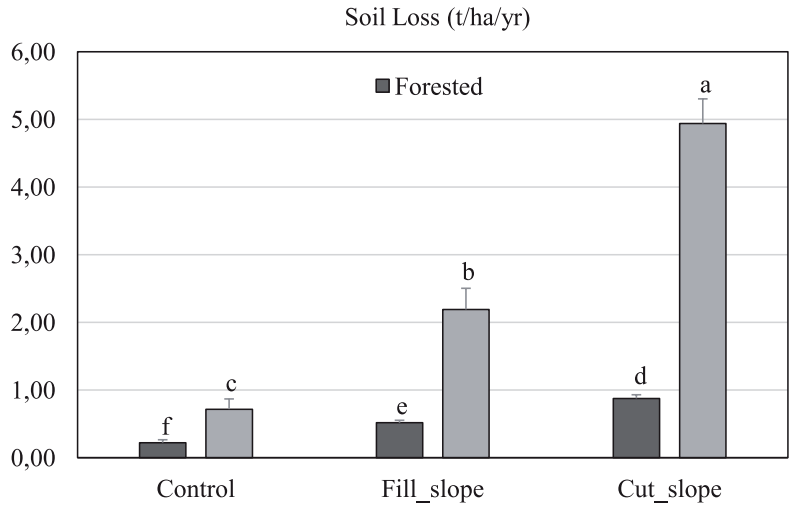

(Mean SE, $\mathrm{n}=10 \alpha=.05$ )

Fig. 5. Soil loss trend in slopes according to land use group (*letters show the statistical differences between means for slope and land use). 
Table 4. Recalculated soil loss group for forested and open areas.

\begin{tabular}{|c|c|c|c|c|c|c|}
\hline \multirow{2}{*}{\multicolumn{2}{|c|}{ Sample point }} & N & \multicolumn{2}{c|}{$\begin{array}{c}\text { Open Area } \\
\text { Subset for alpha }=.05\end{array}$} & \multicolumn{2}{c|}{$\begin{array}{c}\text { Forest } \\
\text { Subset for alpha }=.05\end{array}$} \\
\cline { 3 - 7 } & 1 & 2 & 1 & 2 & 1 \\
\hline \multirow{3}{*}{$\begin{array}{c}\text { Tukey } \\
\text { HSD(a) }\end{array}$} & Control & 10 & 2.07439120 & & .45125990 & \\
\cline { 2 - 7 } & Fill slope & 10 & 2.14251720 & & .47709530 & .61931430 \\
\cline { 2 - 7 } & Cut slope & 10 & & 3.03724590 & & 1.000 \\
\cline { 2 - 7 } & Sig. & & .841 & 1.000 & .664 & \\
\hline
\end{tabular}

*Means for groups in homogeneous subsets are displayed

area), soil loss, clay, $\mathrm{pH}$, wilting point, and saturated hydraulic conductivity were significantly changed $(\mathrm{p}<0.05)$ in control points, and fill slope, silt, $\mathrm{pH}$, and soil loss were significantly $(\mathrm{p}<0.05)$ altered, while the $\mathrm{L}$ factor and soil loss were different $(p<0.05)$ in cut slope. Finally, according the land use type, soil loss trend was significantly changed $(p<0.001)$ in control, fill slope, and cut slope (Fig. 5). The average soil loss was $2.62 \mathrm{t} / \mathrm{ha} / \mathrm{yr}$ in the open area and $0.54 \mathrm{t} / \mathrm{ha} / \mathrm{yr}$ in the forested area.

\section{Scenario-Based Recalculation of Soil Loss Amounts in Slopes for Forested and Open Areas under the Same $S$ and L Factor Conditions}

LS factor was determined as one of the most effective factors in soil loss equation $(A B A G)$. For this reason, these factor components were assumed to be constant for all control points and slopes and was tried to reduce its effect. The soil loss amounts were recalculated in the case of slope gradient $68.72 \%$ and slope length $3.26 \mathrm{~m}$ (average of 60 sample points). Two soil loss groups were created for both forested and open areas (Table 4). According to this scenario, differences between control and fill slopes in forested and open areas were not important $(p>0.05)$, while the calculated soil loss for cut slopes was significantly different $(p<0.001)$ from the control and fill slopes. In addition, soil loss in slopes was significantly changed $(\mathrm{p}<0.001)$ according to land use groups (Fig. 6). Zemke [12] calculated an average soil loss $0.05 \mathrm{t} / \mathrm{ha}$ in the undisturbed forest area, $0.13 \mathrm{t} / \mathrm{ha}$ in the vegetated skid trail, and $1.95 \mathrm{t} / \mathrm{ha}$ in the unpaved road surface after a 90-minute rainfall simulation. Also, it has been reported that almost all of the soil loss on the road routes originated from the road surface, cutslope, and fill slope [28].

As a result of evaluation according to land use, the highest soil loss value was found in the cut slope in open and forested areas. The LS factor, which is a component of slope and slope length, played an important role in soil loss. It has also been reported in previous studies that the amount of soil loss increased by length of cut slope [12]. Besides, the amounts of soil loss in the slopes of open and forested areas, including the control point, were significantly different from each other due to $\mathrm{K}$ and
LS, which constitute the most important components of soil loss and were significantly different in slopes. In the created scenario, even using fixed LS value did not prevent significant soil loss in the cut slope. Therefore, K factor played the most important role in soil loss and this factor coefficient is highly related to soil type [36]. The K factor value could be improved by soil properties such as organic matter, sand, fine sand, silt, and soil permeability [25].

According to land use, soil loss in the slopes was significantly different due to the "C" factor, which is one of the most important components of soil loss. The created scenario also supported this event. In previous studies it was reported that the $\mathrm{C}$ factor plays an important role on surface runoff, erodibility, and soil erosion [37-39]. It is reported that in the long run, by vegetation efforts along with cut slope and fill slope, soil loss can be reduced by at least 30\% and this ratio can reach $90 \%$ [27]. As a precaution in the short term, and geotextile and blanket applications in slope have been reported to decrease soil loss [40] significantly and improve soil quality properties [41]. Also, soil properties affecting $\mathrm{K}$ value affect the soil loss in cut and fill slope through to the forest road [42]. When our study area (forested and open areas) and slopes are evaluated in terms of soil loss in general, annual soil loss in hectares was calculated as $<5.0$ ton/yr; and in the less sensitive category of erosion according to the results in a tropical region [43]. But this value could

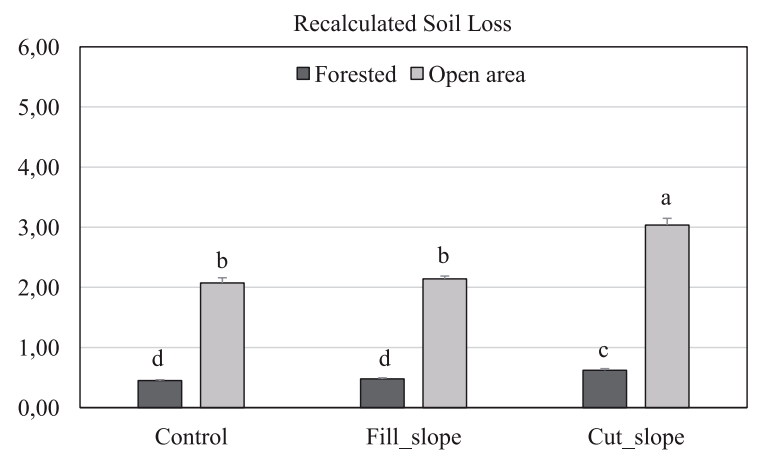

(Mean SE, $\mathrm{n}=10 \alpha=.05$ )

Fig. 6. Recalculated soil loss trend in slopes according to land use group (*letters show the statistical differences between means for slope and land use). 
be understood as very high because of the ecological conditions in the subtropical regions of the globe [44].

\section{Conclusions}

It has been determined that the cut slope and fill slope surfaces formed because of forest road construction are significantly effective in soil loss. In this study, significant differences were determined between the control points and the amount of soil loss between the cut and fill slope surfaces. LS, K, and C were determined as the most effective factors in soil loss for fill and cut slopes of forested and open areas. Since the LS factor (fixed) cannot be influenced during road construction work, as a permanent precaution, the $\mathrm{C}$ factor can be adjusted by plantation efforts, and geotextile and blanket applications may be used for temporary precautions. By improving soil properties, the $\mathrm{K}$ factor can be modified and the soil losses in the slopes can be reduced. In addition, during road construction work, the layer of organic matter stripped from the topsoil can be added to the fill and cut slopes to improve the $\mathrm{K}$ factor. However, this procedure may be difficult for cut slope because of the high slope value.

\section{Acknowledgements}

This study was investigated with the support of Karadeniz Technical University. The physical, chemical, and hydrological analyses are done in the laboratories of the forest faculty. We give special thanks to the Regional Forest Directorate of Trabzon for their permits and help.

\section{Conflict of Interest}

The authors declare no conflict of interest.

\section{References}

1. ZHANG Z., SHENG L., YANG J., CHEN, X-A., KONG L., WAGAN B. Effects of land use and slope gradient on soil erosion in a red soil hilly watershed of southern China. Sustainability, 7, 14309, 2015.

2. MAETENS W., VANMAERCKE M., POESEN J., JANKAUSKAS B., JANKAUSKIENE G., IONITA I. Effects of land use on annual runoff and soil loss in Europe and the Mediterranean: A meta-analysis of plot data. Progress in Physical Geography. 36 (5), 599, 2012.

3. WANG J., WANG H., CAO Y., BAI Z., QIN Q. Effects of soil and topographic factors on vegetation restoration in opencast coal mine dumps located in a loess area. Sci. Rep. 6, 22058, 2016

4. FERREIRA V., PANAGOPOULOS T., ANDRADE R., GUERRERO C., LOURES L. Spatial variability of soil properties and soil erodibility in the Alqueva reservoir watershed. Solid Earth, 6, 383, 2015.
5. BERENDSE F., VAN RUIJVEN J., JONGEJANS E., KEESSTRA S. Loss of plant species diversity reduces soil erosion resistance. Ecosystems, 18, 881, 2015.

6. NEARING M.A., XIE Y., LIU B., YE Y. Natural and anthropogenic rates of soil erosion. International Soil and Water Conservation Research, 5, 77, 2017.

7. HARTMANN, M., HOWES C.G., VANINSBERGHE D., YU H., BACHAR D., CHRISTEN R., NILSSON R.H., HALLAM S.J., MOHN W.W. Significant and persistent impact of timber harvesting on soil microbial communities in Northern coniferous forests. ISME J., 6 (12), 2199, 2012.

8. PARSAKHOO A., LOTFALIAN M., KAVIAN A., HOSSEINI S.A. DEMIR M. Prediction of the soil erosion risk in a forest and sediment yield from road network through GIS and SEDMODL. International Journal of Sediment Research. Code No. 1131, 2011.

9. ARUGA K, SESSIONS J, AKAY A.E. Heuristic planning techniques applied to forest road profiles. J For Res-JPN, 10, 83, 2005.

10. ZIEGLER A.D., GIAMBELLUCA T.W., SUTHERLAND R.A., NULLET M.A., YARNASARN S., PINTHONG J., PREECHAPANYA P., JAIAREE S. Toward understanding the cumulative impacts of roads in upland agricultural watersheds of northern Thailand. Agric. Ecosyst. Environ. 104, 145, 2004

11. LUCE C.H., BLACK A.T. Sediment production from forest roads in western Oregon. Water Resources Research, 35 (8), 2561, 1999

12. ZEMKE J.J. Runoff and soil erosion assessment on forest roads using a small scale rainfall simulator. Hydrology, $\mathbf{3}$ (25), 1, 2016

13. FORMAN R.T.T., ALEXANDER L.E. Roads and their major ecological effects. Annu. Rev. Ecol. Syst. 29, 207, 1998.

14. SAFARI A., KAVIAN A., PARSAKHOO, A. Assessment of effect of road or road construction on soil physical and chemical properties in northern forests of Iran. International journal of Advanced Biological and Biomedical Research. $1(8), 2013$.

15. ZEMKE J.J., KÖNIG D. Abflussbildung und bodenerosion auf forstwegen. Geogr. Rundsch., 68, 46, 2016.

16. NASIRI M., HOSSEINI S.A. Effect of LS factor on soil loss rate from cut slopes after the construction of forest roads. Journal of Environmental Science and Management $15(2), 13,2012$

17. WALTER H., HARNICKELL E., MUELLER-DOMBOIS D. Climate-diagram maps of the individual continents and the ecological climatic regions of the earth. Berlin: Springer-Verlag. 36 p. with 9 maps, 1975.

18. MGM (Turkish State Meteorological Service). Turkey. Avaliable online: https://www.mgm.gov.tr/iklim/iklimsiniflandirmalari.aspx?m=GUMUSHANE (accessed on 10 October, 2017).

19. BOUYOUCOS G.J. Hydrometer method improved for making particle size analyses of soils. Agronomy Journal, 54, 464, 1962.

20. ALLISON L.E. Organic Carbon: Walkley-Black Method. In: Methods of Analysis. Agronomy Monographs No: 9, Part 2. American Society Agronomy, Madison, Wisconsin, USA, 1367, 1965.

21. SAXTON K.E., RAWLS W.J., ROMBERGER J.S., PAPENDICK R.I. Estimating generalized soil-water characteristics from texture. Soil Sci. Soc. Amer. J., 50 (4), 1031,1986 
22. B.K. Bodenkundlische Kartieranleitung, 4. Auflage, E. Schweizerbart Verlagsbuchhandlung, Hannover, 1994.

23. SCHWERTMANN U., VOGL W., KAINZ M. Bodenerosion durch Wasser: Vorhersage des Abtrags und Bewertung von Gegenmassnahmen, Ulmer Verlag, Stuttgart, 1990

24. DOĞAN O., GÜÇER C. Su erozyonunun nedenleri oluşumu ve üniversal denklem ile toprak kayiplarinin saptanmasi, Ankara, 1976 [In Turkish].

25. SHABANI F., KUMAR L., ESMAELI A. Improvement to the prediction of the USLE K factor. Geomorphology, 204, 229, 2014.

26. PEREIRA P., GIMEİNEZ-MORERA A., NOVARA A., KEESSTRA S., JORDÁN A., MASTO R.A., BREVIK E., AZORIN-MOLINA C., CERDÀ A. The impact of road and railway embankments on runoff and soil erosion in eastern Spain. Hydrol. Earth Syst. Sci. Discuss., 12, 12947, 2015.

27. JORDAN A., MARTINEZ-ZAVALA L. Soil loss and runoff rates on unpaved forest roads in southern Spain after simulated rainfall, Forest Ecology and Management, 255 (3), 913, 2008.

28. SEUTLOALI K.E., BECKEDAHL H.R. A review of roadrelated soil erosion: an assessment of causes, evaluation techniques and available control measures. Earth sci. res. j., 19 (1), 73, 2015.

29. PANAGOS P., BORRELLI P., POESEN J., BALLABIO C., LUGATO E., MEUSBURGER K., MONTANARELLA L., ALEWELL C. 2015. The new assessment of soil loss by water erosion in Europe. Environmental Science \& Policy, 54, 438, 2015.

30. BREETZKE G. D., KOOMEN E., CRITCHLEY W. R. S. GIS-assisted modelling of soil erosion in a South African catchment: evaluating the USLE and slemsa approach. Water Resources Planning, Development and Management, Chapter 3, 53, 2013.

31. KUSUMANDARI A. Soil erodibility of several types of green open space areas in Yogyakarta city, Indonesia. Procedia Environmental Sciences, 20, 732, 2014.

32. ARNA'EZA J., LARREAB V., ORTIGOSA L. Surface runoff and soil erosion on unpaved forest roads from rainfall simulation tests in northeastern Spain. Catena, 57, $1,2004$.

33. ZHANG J.C., DEANGELIS D.L., ZHUANG J.Y. Spatial variability of soil erodibility ( $\mathrm{k}$ factor) at a catchment scale in Nanjing, China. Theory and Practice of Soil Loss Control in Eastern China 101, 2011.
34. DINDAROĞLU T., CANBOLAT M.Y. Hidrolojik fonksiyonlu havzalarda fizyoğrafik karakteristiklere ve arazi kullanimina bağlı olarak toprak özelliklerindeki değişimin araştırılması. Turkish Journal of Forest Science, 1 (1), 10, 2017 (In Turkish).

35. ÖZALP M., ERDOĞAN YÜKSEL, E., YILDIRIMER S. Subdividing large mountainous watersheds into smaller hydrological units to predict soil loss and sediment yield using the GeoWEPP model. Pol. J. Environ. Stud., 26 (5), $2135,2017$.

36. NUKET B. 2010. Using the geographical information system and remote sensing techniques for soil erosion assessment. Polish J. of Environ. Stud., 19 (5), 881, 2010.

37. ZHAO W.W., FU B.J., CHEN L.D. A comparison between soil loss evaluation index and the C-factor of RUSLE: a case study in the Loess Plateau of China. Hydrol. Earth Syst. Sci., 16, 2739, 2012.

38. KUOK KELVIN K.K., MAH DARRIEN Y.S., CHIU P.C. Evaluation of $\mathrm{C}$ and $\mathrm{P}$ factors in universal soil loss equation on trapping sediment: Case study of Santubong River. Journal of Water Resource and Protection, 5, 1149, 2013.

39. KARAMAGE F., ZHANG C., KAYIRANGA A., SHAO H., FANG X., NDAYISABA F., NAHAYO L., MUPENZI C., TIAN G. USLE-Based assessment of soil erosion by water in the Nyabarongo River Catchment, Rwanda. Int. J. Environ. Res. Public Health, 13, 835, 2016.

40. SMETS T., POESEN J., LANGHANS C., KNAPEN A., FULLEN M. A. Concentrated flow erosion rates reduced through biological geotextiles. Earth Surface Processes and Landforms, 34 (4), 493, 2009.

41. BHATTARAI R., KALITA P.K., YATSU S., HOWARD H.R., SVENDSEN N. G. Evaluation of compost blankets for erosion control from disturbed lands. Journal of Environmental Management, 92 (3), 803, 2011.

42. TURK Y. The Effect of soil properties on landslides along forest road. Eur J Forest Eng, 3 (1), 1, 2017.

43. MOLLA T., SISHEBER B. Estimating soil erosion risk and evaluating erosion control measures for soil conservation planning at Koga watershed in the highlands of Ethiopia. Solid Earth, 8, 13, 2017.

44. HACISALIHOGLU S., YUCESAN Z., OKTAN E., OZCELIK S. Soil loss under different release cutting Intensities in an artificial oriental beech (Fagus orientalis lipsky.) stand, Austrian Journal of Forest Science, 130, 255, 2013. 
